\title{
Palladium-Catalyzed Synthesis of Isatins from Anilines by Double Carbonylation
}

Gategory

Synthesis of

Heterocycles

Key words

isatins

palladium catalysis

carbonylation

anilines

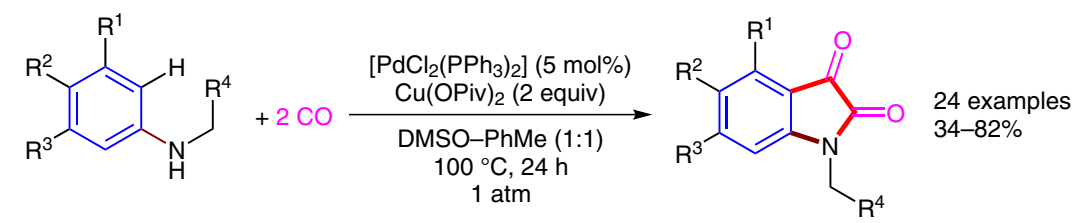

also

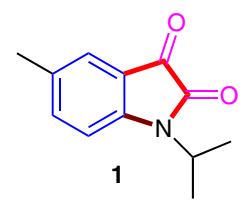

$34 \%$ yield

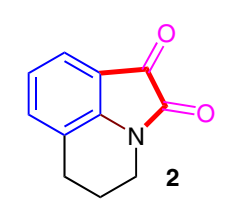

$38 \%$ yield<smiles>Cc1ccc2c(c1)C(=O)C(=O)N2/C=C/C(C)C</smiles>

$\mathrm{R}^{1}=\mathrm{H}, \mathrm{Me}$

$\mathrm{R}^{2}=\mathrm{Me}, t-\mathrm{Bu}, \mathrm{Ph}, \mathrm{F}$

$\mathrm{R}^{3}=\mathrm{Me}, \mathrm{Cl}, \mathrm{F}$

$\mathrm{R}^{4}=\mathrm{H}, \mathrm{Me}, n-\mathrm{C}_{5} \mathrm{H}_{11}, c-\mathrm{Pr}, \mathrm{Ph}, 3-\mathrm{F}_{3} \mathrm{CC}_{6} \mathrm{H}_{4}, 2-\mathrm{F}_{3} \mathrm{CC}_{6} \mathrm{H}_{4}, 4-\mathrm{F}_{3} \mathrm{CC}_{6} \mathrm{H}_{4}, 2-\mathrm{FC}_{6} \mathrm{H}_{4},\left(\mathrm{CH}_{2}\right)_{2} \mathrm{Ph}, \mathrm{CH}_{2} \mathrm{OPh}$, 2-Naph

Significance: Lei and co-workers report a palladium-catalyzed synthesis of isatins by double carbonylation and ortho $\mathrm{C}-\mathrm{H}$ bond activation of aniline derivatives. Poor to good substrate scope was observed under the optimized reaction conditions. A mechanism is suggested, in which palladium $\mathrm{C}-\mathrm{H}$ bond insertion is followed by the two consecutive $\mathrm{CO}$ insertion reactions.
Comment: The isatin structure has been given privileged status because of the generation of a large number of structurally diverse derivatives which inhibit cancer cell proliferation and tumor growth by interaction with a variety of intracellular targets such as DNA, telomerase, tubulin, P-glycoprotein, protein kinases, and phosphatases (K. L. Vine, J. M. Locke, M. Ranson, K. Benkendorff, S. G. Pyne, J. B. Bremner Bioorg. Med. Chem. 2007, 15, 931). In the present methodology, substrates and catalysts were inadequately studied. The origin of poor yields (e.g., $\mathbf{1}$ and $\mathbf{2}$ ) were also unidentified. 